\title{
A Multi-perspective Analysis of Robinson's Pioneering Spirit
}

\author{
Jie Li \\ School of Social Sciences and Humanities \\ Qingdao Agricultural University \\ Qingdao, China
}

\begin{abstract}
Robinson is a literary image with a pioneering spirit and has a far-reaching influence in the world literacy. This paper investigates both the cultural connotation and the roots and points out that cultural connotation include three perspectives: breaking with tradition; standing up to the earth and never giving up; innovating and forging ahead. In the era of modernization and globalization, this literacy image and its representative cultural sources still have irreplaceable significance.
\end{abstract} value

Keywords—Robinson; cultural connotation; pioneering spirit;

\section{INTRODUCTION}

"Robinson Crusoe", a classic work written by Defoe, who was a British writer in the 18th century, is "the first British real novel". Defoe originally created a literary image with tenacious struggle on the island, not only to survive, but also to create their own "material kingdom" and "spiritual kingdom". The specific background of the times and the author's talent create the glorious image of Robinson with the special characteristics that ordinary people don't have. Robinson's spirit is very instructive and it is worth to examine the life values and the spirit.

\section{ROBINSON'S PIONEERING SPIRIT}

Robinson is not only a hero, but also a legend. His life is not fixed early, but is created by his own spirit of rebellion and courage. It is his pioneering spirit that creates him a miracle life.

\section{A. Breaking up with Traditions and Being Brave in Exploration}

Robinson was born in a poor family, and his family hoped that he could learn laws and be a judge in the future, living with a stable life. This is in line with the prevailing social traditions and people's thinking is shackled by the model of doing business and political career.

However, Robinson was eager to adventure in his childhood and not satisfied with the status quo, hoping to pursue his expected life. Therefore, he gave up the accessibly available status, money and comfort, regardless of the oppositions from his beloved ones. During the journey, he encountered many dangers especially strong storms, but he was not afraid of danger and didn't change his mind for adventure even when he was arrested to be a slave by the pirates.

As he said, "But the wind stopped the next day, I put aside the idea of going home after the voyage, however, I always refused to change my mind at the moment of forthcoming disaster and plunged myself to the life once the danger passed" (Defoe, 2009, P.32).

A witness can be seen from his various experiences that Robinson is pursuing a new orientation via breaking with traditions. In reality, many people lost their dreams for lacking of courage, however, Robinson walked out a path of youth with his firm belief.

\section{B. Standing up to the Earth and Never Giving up}

Survival was the problem that Robinson had to face up with when he arrived a lonely island. He was living in the island without any persons, foods, water and houses. He was overwhelmed with contradictions, helpless and desperation. As he said, "If I can survive and walk on the land again, I promise to go home without any hesitations and will never go to sea in the rest of my life. I will listen to my father's advice and will not choose this road. In a word, I will decide to be a penitent prodigal and come into father's arms" (Defoe, 2009, P.38).

However, soon he was not desperate anymore because he changed his situation with his actions. He returned to the boat and found some necessities and then tried to plant crops in order to feed himself in a long term. This made him believe that he could continue his adventurous life.

He was a person standing up to the earth without complaints to others. His spirit of being practical and never giving up was more effective in finding residence. He spent a whole day in finding out a temporary shelter under a rock when he first arrived the island. Later, he put up the tent, bang the stakes, made the fences and decorated the ceiling. Next, he tried to learn hunting, plant crops, tame goats and also explored to make tables, potteries and bread and so on.

Robinson said "I often sat down to eat with my gratitude to the God for his granting me rewards in the desert island and giving me hope when I was in desperate" (Defoe, 2009, P. 48). 
God's "Good Deeds" was realized by his great efforts. Robinson was a practical person but not a dreamer. Although the situations were worse, he still found ways to survive in the lonely island successfully. This reflects that Robinson is a real hero with perseverance who will never give up in front of difficulties.

\section{Innovating and Forging ahead}

Firstly, Robinson decided to establish new relationships. He had a strong desire to kill the savages when he saw them eating a living person. At last, he got the chance. While the savages were holding a "banquet", Robinson saw a person running way from the "banquet". He shot the two savages and saved that running person's life, who later became Robinson's slave named "Friday" by Robinson. With the help of Robinson, "Friday" learned the basic survival skills quickly, such as planting crops, hunting, believing in Christian, speaking English and etc.. He was Robinson's only friend as well as the most loyal slave in the island.

Robinson opened the heart of "Friday" in a special way by giving him an human identity, thus they became real friends who talked everything with each other. Robinson was kind in nature and accepted "Friday". He established an "impossible" interpersonal relation. Finally, a ship came, however, there were internal conflicts among the sailors. This gave Robinson the chance to kill the rioters and the captain and the first chief mate were saved.

Robinson established the interpersonal circle with his kindness and unique way of doing things. Although it is small, it is rare. Only in a helpless situation, one can cherish the friendship. Robinson was not born to be a clubman, but he continued to live, making great effort even in his desperation.

Secondly, Robinson established his own plantation in Brazil, creating the "Kingdom" for his career. He authorized his friend to manage the plantations and left the island where he stayed for 28 years. When he returned to his hometown, his parents already had passed away, which is his most regretful thing. He had expected to show his filial respect for his parents, but now they were not there. Later he married and had his own children, however, he continued to risk after staying at home for a short time.

With his indomitable spirit, Robinson created a huge fortune and founded his own "material kingdom". He made a great success in materials, which is unbelievable for ordinary people. Although the material is not a standard to measure a person's success, the material achievement is a strong symbol to prove one's life.

At the same time, Robinson's life has also been sublimated for he not only created his legend, but also impressed many people. Returning hometown, he was painful in losing relatives, however, he cheered up soon and continued his adventurous trip. Encouraged by his pioneering spirit, Robinson realized his life value, created his own "Kingdom of Spirit", optimized his mind and enhanced his spiritual plane.
Everyone has his own "Kingdom", and loves that. Robinson made it with great efforts and perseverance. Should we have a try? Then our life values would be maximized and we will have a colorful life.

\section{CAUSES OF ROBINSON’S PIONEERING SPIRIT}

The reasons for vivid image of Robinson are not just the extraordinary character in the novel or purely the fantastic idea from the author-Defoe, but are closely related to the time, political and economic background which represent the distinctive features of that period of time. Also, the author's personal life experience determines the positional tendency of the whole novel. All these factors are integrated together so that the image of the Robinson in the novel can be established.

\section{A. Times Factor}

As the old saying goes "times make heroes". The exceptional achievements of Robinson are made out of that period of time. Remolded by the time, Robinson finally finds the real meaning of life and realizes the value of his life.

1) Economic factors: Robinson is living in the booming period of the capitalism which the bourgeoisie is coming into force. The productive way and production relations in social-economical system change enormously, and the handicraft industry and business industry have obtained great achievement. The original means of production can't meet the demand of the new emerging bourgeoisie. In order to seek more social wealth, new land production base and new market, the new emerging bourgeoisie are having some adventures. With the emerging of the civilian class bringing the spread of the enlightenment thought, the new emerging bourgeoisie begins paying more attention to social reality and more on the seeking of wealth, which is contradict from the traditional idea of taking up politics and business. However, the new idea of the bourgeoisie is more advanced at that time, thus the new emerging bourgeoisie is doomed to take adventures and expand overseas.

2) Political background: Compared with the landlord class who sits idly and enjoys the fruits of prior work, the bourgeoisie is more advanced. At the same time, the bourgeoisie has hold a dominate position in Europe and its dominance in Europe has risen the curtain. The progressive aspect of the bourgeoisie is represented in its adventure quality. The landlord class seldom considers making progress, while the bourgeoisie is daring to do everything. In order to consolidate the position of the bourgeoisie and propagate the capitalism, adventuring outside and exploring overseas are becoming the aim for the bourgeoisie.

3) Thoughts of adventures for wealth overseas: The development of the capitalism requires the accumulation of the capitals, adventuring for seeking wealth overseas is definitely a trend for the new emerging bourgeoisie. They are eager to take a try, which causes the formation of this positive thought and progressive idea in their mind unconsciously, therefore, which makes the spirit of 
adventuring overseas upgrade to a great extent under this social trend. In fact, Robinson is just one of representative bourgeoisie who are keen on taking adventures. Although many people intend to try, most of them hold the attitude of waiting and seeing. No people are willing to give up their comfortable life to explore overseas because it is likely to be at the cost of their lives. Thus, another "Robinson" would appear even without this Robinson.

\section{B. The Author's Unique Life Experience}

Defoe's unique life experience also has an effect on the creating of the novel. Defoe has a particularly rich life experiences. He was born in a business family and had experienced varieties of business activities. He once operated a brick and tile factory. It was not exaggerating to say that Defoe had once set a foot into all kinds of areas: entering English political circle and even becoming the bourgeoisie politician. He was arrested due to engaging in some sensitive political activities and finally being discharged from the prison through the improving the relationship. From then on, Defoe continued to operate newspapers and journals and then was put into prison several times due to his inappropriate expression of the ideas. After he finished the producing of the novel Robinson Crusoe, he was over sixtyyear-old. But it is a real long novel in the history of English literature.

In the early days of 18th century, the story that a Scottish sailor Alexander Selkirk survived alone in a deserted island and returned to his home town after four years shocked the whole Britain. This story was popular to everyone and being told at each corner of the streets. Defoe was inspired by the experience of this sailor and later created the novel based on this story. The story recreated by Defoe that brought us many enjoyment and reflection is called Robinson Crusoe. Through his unique sight and refined thinking mode, Defoe created a master piece of novel based on the real life story. Thus Defoe was called the "father of the novel in Europe".

Defoe created this classic novel through his carful observation and reflection of the life, which contributed the image of Robinson and his success as well. Therefore, it was Defoe who bestowed the soul of Robinson, and it was Defoe who made the characters live and vivid with the positive power.

\section{SIGNIFICANCE OF ROBINSON's PIONEERING SPIRIT}

In "Robinson Crusoe", Robinson's glorious image has left a deep impression. His pioneering spirit propels the future pursuit of free life and adventure of the young bourgeoisie with a strong impetus. The bourgeoisie represents the progressiveness of the times. The emerging bourgeoisie is eager to go out to see the world, in pursuit of free life and more adventures. Robinson's success has just inspired the gang of these aspiring young people, encouraging them to go out looking for new base, new materials and the alike. It caters to the needs of social development at that time. Hence the more attention it has gained.
In fact, in the real life, not only the eighteenth-century British society needs "Robinson", today's society also needs his pioneering spirit, as brave and courageous as him in face of difficulties - the spirit of seeking new directions should also become a trend in today's society. Therefore, Robinson's image is not confined within national borders, times or space, but rather has profound social significance. By analyzing the pioneering spirit of Robinson, we should also learn a lot of life philosophy.

\section{A. Function of Wake-up for Society}

Robinson is a very bold adventurer. In the absence of any preparation of the circumstances, blind adventures brought him to a lot of tests of life, but they did not polish his will, his independent life on the island bring the most wonderful part of the text, in which human wisdom and creativity have been fully explored and the adventurer's life journey can also be traced. Sometimes this is what lack in real life. It is easier to take challenges when we are fully prepared, but sometimes things in reality do not wait until you are ready. It simply comes up and charges a more challenging heart, the one that we are in need of. So this kind of "blindness" is thought-provoking.

Robinson's spirit may not be appreciated by some people, but it has caused a huge social repercussions and increased people's courage. Robinson's experience provided some explanation to the inevitable trend of capitalist development in the overseas expansion, mirroring the real picture of the society at that time. Flowing in the enthusiastic hearts of the young generation, Robinson's spirit has paved the way for the development of capitalism.

Of course Robinson is not perfect; instead, he is undoubtedly a bourgeois. His overseas adventure caters only to his own greedy desire. This exploitation of the bourgeoisie for the new land and new production base has inflicted the invaded people with unbearable suffering, opening the curtain of the tragedy of black slavery trade. It can be said that the colonial countries have paid a high price for the consequences of capitalist development.

Behind the goodness of Robinson lies also his indifference. When his wife died, he suffered only a moment of sadness before he continued his overseas adventure. What Robinson has done on his benefactor Xury has further more reflected his indifference. When Xury wanted to take his life to express his loyalty to Robinson, Robinson decided to love him and promised to turn him into a great figure. However, when the Portuguese captain is willing to pay for a considerable amount of money, Robinson wavered. With a pretentious, reluctant look in his eyes, he eventually betrayed Xury.

Of course, this cannot be completely blamed on Robinson. It is the limitations of the bourgeoisie that have determined the fate of Xury. We can't completely deny the character image of Robinson, since there is no perfection in anybody. The positive energy he passes on can clearly be received. We can't deny the whole character image because of a little bit of flaws. We are to learn these positive images to inspire ourselves. 


\section{B. Function of Revelation for Literature}

At the beginning of the 18th century, Dr. Johnson, a great man in the English literary world, believes that in the literary creations, there is no longer texts that readers can ever expect other than Don Quixote, Robinson Crusoe and The Pilgrim's Progress. It is the significant status of Robinson Crusoe. Robinson became a hero of the struggle of fate, so it is regarded as a worldly immortal masterpiece in the most rigorous sense of the word. It is considered to have shaped the modern civilization, as one of the few literary works that have impact on the history of mankind. Many other literary works have also created some of the characters with pioneering spirit, and also instilled some of Robinson's spirit into the characters. It has become the spiritual pillar for those in pursuit of freedom and independent will, called for social change and progress for future generations, and provided a good reference for many adventure novels coming out later.

\section{CONCLUSION}

"Robinson", in Daniel Defoe's work, has personal independence of conduct at that time and also had a positive impact on the afterworld. Today's society is developing and advancing one with the times. We need to understand the cultural connotations of "Robinson's Spirit", engraving it in everyone's heart.

Nowadays, the materials are rich enough and many people are satisfied with the comfortable life. Some people lost their life aims during the process of enjoying the materials, some even wanted to succeed without any pains. On the one hand, they complained the corruptions in the society, but on the other hand, they didn't take any actions. Some complain the conditions are not good enough for them to realize their goals; while some don't put it into practice even the conditions are enough. They have no courage to risk themselves. One can be successful in adversity as well as in prosperity because value of life is one's only target. How can one realize his value of life without any actions?

Xiong points out that "the ultimate goal of modern educational spirit is to effectively promote the development of ethnic culture, call for new ethnic spirit and to direct scientific and rational spirits under the guidance of spirits: truth-seeking spirits, adventurous spirits, pioneering spirits, competitive spirits, friendly spirits, honest spirits, diligences and dedications" (Xiong, 2012, P. 46).

Robinson's spirit typically represents this kind of educational spirit, which is worth for everyone to learn. This has implications for both individuals and the whole nations. We are not marching alone in the storms for we have our spiritual substance and capital for struggles. Today, there is no Robinson's nightmare rather there is more comfortable circumstance. Therefore, we should be courageous enough with hard-working, because where there is struggle, there is the future. This is the most meaningful, valuable and colorful life.

\section{REFERENCES}

[1] Daniel Defoe, Robinson Crusoe, Shanghai: Yinlin Publishing House, 2009.

[2] Xiong, W. C. China's Educational Spirit, Beijing, Renmin's University Press, 2012.

[3] Chen L, Robin and post-colonialism, Changsha, Journal of Changsha Railway Institute, 2004.

[4] Wang J Y, Interpretation of Robinson's Spirit, Liaoning University Press, 2003.

[5] Zheng K L, History of Foreign Literature, Beijing, Higher Education Press, 2006. 